\title{
Pengaruh Media Budidaya Menggunakan Air Laut dan Air Tawar terhadap Sifat Kimia dan Fungsional Biomassa Kering Spirulina platensis
}

\author{
The Effect of Cultivation Medium in Marine and Fresh Water on Chemical Composition and Functional Properties \\ of Dry Biomass Spirulina platensis
}

\author{
Nurfitri Ekantari', Yustinus Marsono², Yudi Pranoto², Eni Harmayani² \\ ${ }^{1}$ Departemen Perikanan, Fakultas Pertanian, Universitas Gadjah Mada, \\ Jl. Flora, Gedung A-4, Bulaksumur, Yogyakarta 55281, Indonesia \\ ${ }^{2}$ Departemen Teknologi Pangan dan Hasil Pertanian, Fakultas Teknologi Pertanian, Universitas Gadjah Mada, \\ Jl. Flora No. 1, Bulaksumur, Yogyakarta 55281, Indoensia \\ Email: nurfitri@ugm.ac.id
}

Submisi: 11 Mei 2016; Penerimaan: 26 Juli 2016

\begin{abstract}
ABSTRAK
Spirulina merupakan mikroalga, mudah dibudidayakan dan dapat hidup dalam tingkat salinitas yang rendah hingga tinggi. Kandungan kimia dalam Spirulina dapat dipengaruhi oleh media budidayanya. Di Indonesia Spirulina platensis yang beredar sebagian merupakan hasil budidaya dari berbagai tempat dengan media budidaya air tawar maupun air laut. S. platensis dapat digunakan sebagai salah satu sumber kalsium karena kandungannya dapat mencapai 700-1000 $\mathrm{mg} / 100 \mathrm{~g}$ biomassa kering. Penelitian ini bertujuan untuk mengetahui pengaruh media budidaya air laut dan air tawar terhadap komposisi kimia dan sifat fungsional dari S. platensis. Parameter kimia yang diamati yaitu komposisi proksimat, kandungan mineral $\mathrm{Ca}, \mathrm{Mg}$ dan $\mathrm{P}$, kandungan gula, pati dan serat pangan. Parameter sifat fungsional meliputi kelarutan, kemampuan mengikat air dan lemak, emulsifikasi dan kemampuan membentuk busa. Hasil penelitian menunjukkan bahwa kandungan abu dan mineral (Ca, Mg, P) S. platensis budidaya air laut lebih tinggi daripada budidaya air tawar. S. platensis asal budidaya laut berpotensi sebagai alternatif sumber kalsium $(512,53 \mathrm{mg} \mathrm{Ca} / 100 \mathrm{~g})$ dengan rasio Ca:P $=1: 1,79$. Kandungan karbohidrat S. platensis hasil budidaya media air laut lebih rendah yaitu $28,41 \% \mathrm{db}$ (gula total dengan nilai $0,09 \% \mathrm{db}$, pati $6,9 \% \mathrm{db}$ dan total serat pangan $24,81 \% \mathrm{db}$ ), serat pangan terutama berupa serat pangan tak larut sebesar $24,18 \% \mathrm{db}$. Sifat fungsional dipengaruhi oleh asal budidaya. Spirulina platensis asal budidaya laut memiliki sifat Water Holding Capacity (WHC) yang lebih tinggi yaitu $4,46 \mathrm{~mL} / \mathrm{g}$ dibandingkan sifat Oil Holding Capacity (OHC) yaitu $2,35 \mathrm{~mL} / \mathrm{g}$, sedangkan Water Soluble Index (WSI), kapasitas membentuk busa dan emulsifikasi tidak dipengaruhi media budidaya.
\end{abstract}

Kata kunci: Kalsium; serat pangan; media air tawar; media air laut; Spirulina platensis

\begin{abstract}
Spirulina is a microalgae, easily cultivated and grows well in a low to high-level of salinity. Chemical contents in Spirulina can be influenced by the conditions of cultivation. Spirulina platensis sold in Indonesia is largerly cultured in marine water or fresh water medium. S. platensis can be used as a source of calcium because it has $700-1000 \mathrm{mg} / 100$ $\mathrm{g}$ of dry biomass. This study aimed to determine the effect of sea water and fresh water cultivation medium on the chemical composition of $S$. platensis. Samples were determined the chemical composition included proximate analysis, mineral content of Calcium (Ca), Magnesium (Mg) and Phosphor (P), total glucose, starch, and dietary fiber. Functional properties were also determined i.e: solubility, water and oil binding capacities, emulsion and foam abilities. The results
\end{abstract}


showed that the content of ash and minerals $(\mathrm{Ca}, \mathrm{Mg}, \mathrm{P})$ of $S$. platensis cultivated in marine water was higher that of $S$. platensis cultivated in freshwater. This results suggested that $S$. platensis cultured in the sea water medium was potential as an alternative source of calcium $(512,53 \mathrm{mg} \mathrm{Ca} / 100 \mathrm{~g})$ with a ratio Ca-P $=1: 1.79$. The carbohydrate content was at least $28,41 \% \mathrm{db}$ (total sugars almost $0,09 \% \mathrm{db}$, starch $6,9 \% \mathrm{db}$ and total dietary fiber $24,81 \% \mathrm{db}$ ). The dietary fiber was dominated by insoluble dietary fiber $(24,81 \% \mathrm{db})$. Functional properties were affected by cultured medium. Spirulina platensis cultivated in marine water exhibited high capacity on Water and Oil Holding Capacities (WHC and $\mathrm{OHC}$ ) that were $4,46 \mathrm{~mL} / \mathrm{g}$ and $2,35 \mathrm{~mL} / \mathrm{g}$, respectively. Water Solubility Index (WSI), foaming capacity, emulsion capacity were not affected by cultured media.

Keywords: Calcium; dietary fiber; fresh water; marine water; Spirulina platensis

\section{PENDAHULUAN}

Spirulina platensis adalah cyanobacteria atau mikroalga (ganggang mikro) hijau biru yang diperkirakan telah ada di planet bumi sejak 3,5 milyar tahun yang lalu. Mikroalga ini mampu tumbuh pada berbagai tingkat salinitas, $\mathrm{pH}$ sangat basa ( $\mathrm{pH} 8-11)$ dengan kandungan senyawa karbonat dan bikarbonat yang tinggi, sehingga $S$. platensis dapat ditemukan di perairan dengan berbagai tingkat salinitas dengan $\mathrm{pH}$ basa, biasanya berkisar 8-11. Kondisi $\mathrm{pH}$ basa memberikan keuntungan dari sisi budidaya, karena relatif tidak mudah terkontaminasi oleh mikroalga yang lain, yang pada umumnya hidup pada $\mathrm{pH}$ yang lebih rendah atau lebih asam (Tri-Panji, 1995). Jiminez dkk. (2003) menjelaskan bahwa biomassa kering S. platensis dapat mencapai 3032 ton per hektar kolam/tahun. Beberapa faktor yang dapat mempengaruhi produktivitas sel dan komposisi S. platensis, yaitu $\mathrm{pH}$, salinitas, intensitas cahaya, suhu dan ion bikarbonat, serta ketersediaan makro dan mikro nutrien dalam lingkungan budidayanya (Ciferri, 1983; Marek dkk., 1987; Planes dkk., 2002). Hu (2004) menambahkan bahwa faktor lingkungan terutama salinitas tidak hanya mempengaruhi fotosintesis dan produktivitas biomassa sel tetapi dapat mempengaruhi bentuk, aliran aktivitas metabolisme seluler yang berdampak pada dinamika komposisi sel.

Selain mengandung protein dalam jumlah yang tinggi kurang lebih sekitar 60\% (Tietze, 2004), Spirulina juga mengandung serat pangan (Belay, 2008) dan dapat mengandung kalsium hingga mencapai 700-1000 mg kalsium per $100 \mathrm{~g}$ biomassa kering. Jika dibandingkan dengan berbagai jenis sayuran kandungan kalsium pada $S$. platensis hampir mencapai 3 kali lipatnya, sedangkan jika dibandingkan dengan susu dan yogurt hampir 4 kalinya (Tietze, 2004). Spirulina dapat digunakan sebagai salah satu alternatif sumber kalsium. Habib dkk. (2008) menyebutkan bahwa konsumsi $4 \mathrm{~g}$ Spirulina dapat digunakan untuk memenuhi sebagian besar kebutuhan kalsium harian. Namun demikian, kandungan kalsium dalam biomassa Spirulina dapat bervariasi yang dipengaruhi oleh media budidayanya.
Kalsium (Ca) dan serat pangan sangat berhubungan erat, beberapa peneliti menyebutkan bahwa serat pangan dapat mempengaruhi absorbsi Ca dalam tubuh. Pada serealia, serat pangan menghambat absorpsi Ca dan fosfor (P) (Urbano dkk., 1999). Penyerapan Ca umumnya terjadi pada bagian ileum dan jejunum. Keberadaan kompleks serat pangan dan Ca dapat menyebabkan penurunan absorpsi. Namun, jika serat pangan dapat mencapai usus besar dan dapat difermentasi oleh bakteri fecal, dapat menghasilkan short chain fatty acid (SCFA) sehingga kondisi menjadi lebih asam dan dapat meningkatkan penyerapan Ca. Dengan demikian, apabila bahan pangan akan digunakan sebagai sumber kalsium, perlu juga dikaji serat pangannya.

Di Afrika dan Mexico selain jenis S. platensis jenis lain yang dikembangkan yaitu S. maxima dan S. fusiformis (Costa dkk., 2002), sedangkan di Indonesia jenis yang berkembang adalah $S$. platensis dan dibudidayakan dengan kondisi yang berbeda terutama media budidayanya dapat berasal dari air laut maupun air tawar. Beberapa penelitian terkait telah dilakukan (Suminto, 2009; Ravelonandro dkk., 2011), namun informasi tentang karakteristik $S$. platensis sebagai bahan pangan fungsional perlu untuk dikaji. Penelitian ini bertujuan untuk mengetahui pengaruh media budidaya air laut dan air tawar terhadap komposisi kimia dan sifat fungsional dari $S$. platensis.

\section{METODE PENELITIAN}

\section{Preparasi Sampel S. platensis}

S. platensis dibudidayakan oleh sebuah produsen mikroalga di Jepara, pada 2 media yang berbeda yaitu air laut dan air tawar. Ketersediaan nutrisi selama budidaya $S$. platensis diperoleh dari pupuk Walne. Proses pemanenan diawali dengan proses pengangkatan biomassa $S$. platensis dari media budidaya, dicuci dengan air tawar, didekantasi dan dikeringkan. Pengeringan menggunakan laminaria dehumidifier pada suhu $50{ }^{\circ} \mathrm{C}$ selama 5 jam. Biomassa kering dihaluskan dan dikemas dalam aluminium foil. Selanjutnya 
dibawa ke Laboratorium Teknologi Pengolahan Ikan, Universitas Gadjah Mada, disimpan pada suhu kamar, sampai dilakukan analisis. Biomassa kering S. platensis dikoleksi dari beberapa batch masa produksi.

\section{Pengujian Aroma, Warna, dan Sifat Fisik S. platensis}

Pengujian aroma dilakukan oleh 10 orang panelis. Panelis mengidentifikasi, mendeskripsikan dan mendiskusikan aroma sampel. Pengujian warna menggunakan chromameter (Konica Minolta, CR-400). Penentuan ukuran partikel dengan sieve test. Densitas $(\mathrm{g} / \mathrm{ml})$ ditentukan dengan metode volumetrikgravimetrik. Sebanyak $5 \mathrm{~g}$ biomassa dimasukkan ke dalam gelas ukur, diketuk-ketuk hingga biomassa set, dan diukur volumenya.

\section{Pengujian Komposisi Proksimat S. Platensis}

Penentuan kadar air dengan metode gravimetri, protein dengan metode mikro kjeldahl, lemak dengan metode soxhlet dan abu dengan metode pengabuan kering (AOAC, 1995). Kandungan karbohidrat ditentukan dengan metode by difference (Winarno, 2008).

\section{Penentuan Kadar Mineral (Ca, Mg dan P) S. platensis}

Kadar $\mathrm{Ca}, \mathrm{Mg}$ dan $\mathrm{P}$ ditentukan dengan metode spektofotometri. Sampel dipreparasi dengan pengabuan basah. Lima gram sampel ditambahkan $10 \mathrm{~mL}\left(\mathrm{HNO}_{3}: \mathrm{H}_{2} \mathrm{SO}_{4}\right.$ : 1:1), didiamkan selama 16 jam ditambahkan $25 \mathrm{ml}$ akuades bebas ion. Larutan dipanaskan hingga berwarna jernih, setelah dingin ditambahkan $25 \mathrm{~mL} \mathrm{HCl}$ dan ditepatkan volumenya hingga $50 \mathrm{~mL}$ dengan akuades bebas ion. Filtrat disaring dan diukur kandungan $\mathrm{Ca}, \mathrm{Mg}$ dan $\mathrm{P}$ dengan spektrofometri Atomic Absorption Spektrofotometer AAS (Perkin Elmer), pada $\lambda=422,7 \mathrm{~nm}(\mathrm{Ca})$ dan $\lambda=285,2 \mathrm{~nm}(\mathrm{Mg})$, kandungan $\mathrm{P}$ ditentukan dengan spektrofotometer (Genesys 20 Thermospectronic, USA) pada $\lambda=440 \mathrm{~nm}$.

\section{Penentuan Kandungan Gula Total, Pati, dan Serat Pangan}

Penentuan gula total dengan metode fenol-asam sulfat (Dubois, 1956), pati dengan metode hidrolisis asam (AOAC, 1995). Serat pangan ditentukan secara enzimatis sesuai metode Asp, serat pangan tak larut (STLA) merupakan residu hasil pengujian, sedangkan serat pangan larut (SLA) diendapkan dengan etanol hangat, total serat pangan dinyatakan sebagai (STLA + SLA) (Asp dkk., 1983).

\section{Pengujian Sifat Fungsional $S$. platensis}

Water Holding Capacity (WHC) dan Water Solubility Index (Kelarutan) ditentukan menurut Onyango dkk. (2004). Pengujian WHC dan kelarutan seperti yang dilakukan oleh Onyango dkk. (2004). Sebanyak 1 g sampel dimasukkan ke dalam tabung falcon yang telah diketahui beratnya, ditambahkan $10 \mathrm{~mL}$ air bebas ion, divortek dan didiamkan selama 30 menit, setiap 10 menit divortek kembali, selanjutnya disentrifugasi (Kokusan H-26 F, Japan) dengan kecepatan 3500 rpm selama 60 menit. Supernatan dimasukkan ke dalam krus yang telah diketahui beratnya dan dipanaskan pada suhu $105{ }^{\circ} \mathrm{C}$ sampai berat konstan untuk mengukur kelarutan (WSI). WHC dihitung sebagai banyaknya air yang terserap dalam pellet. Oil Holding Capacity ditentukan menurut (Subagio, 2006), dilakukan seperti pengujian WHC, dengan mengganti air bebas ion dengan minyak jagung. Emulsion Capacity (EC) menurut Yu dkk. (2007), 2 g sampel ditambahkan $200 \mathrm{ml}$ akuades dihomogenasi dengan blender (Philips, HR-2071) kecepatan 5 selama 2 menit. Sebanyak $200 \mathrm{ml}$ minyak yang telah diberi pewarna diteteskan dengan kecepatan 60 tetes/menit, larutan dihomogenkan dan diperiksa emulsinya setiap 2 menit. Jika terjadi pemisahan yang jelas, penambahan minyak dihentikan. EC merupakan volume minyak yang teremulsi/ sampel (g). Foam Capacity (FC) ditentukan menurut Makri dkk. (2005). Sebanyak 2 gram sampel ditambahkan air $100 \mathrm{~mL}$, volume diukur (V1) dihomogenkan dengan blender dengan kecepatan 5 selama 3 menit. Larutan dituangkan dalam gelas ukur, busa yang terbentuk diukur volumenya (Vf):

$$
(\mathrm{Vf}), \mathrm{FC}=\mathrm{V} 1 / \mathrm{Vf}
$$

\section{Analisis Data}

Data dianalisis dengan t-test, untuk menguji data berdistribusi normal digunakan Uji Kolmogorov-Smirnov. Analisis data menggunakan perangkat lunak SPSS versi 20 dengan tingkat kepercayaan 95\%.

\section{HASIL DAN PEMBAHASAN}

\section{Karakteristik Fisik Biomassa Kering Bubuk $S$. platensis}

S. platensis merupakan sianobakteria yang bersifat kosmopolit dan dapat hidup pada habitat yang ektrim serta dapat hidup pada tingkat salinitas yang tinggi, $\mathrm{pH}$ basa 8-11. Aroma alamiah Spirulina segar cenderung seperti bau rumput laut segar dengan sedikit aroma amis. Perbedaan aroma (Tabel 1) disebabkan oleh media budidaya yang digunakan. Aroma amis pada budidaya dengan air laut distimulir oleh adanya garam mineral. Aguero dkk. (2003) mengidentifikasi sebanyak 54 senyawa volatil dalam $S$. platensis dan menemukan sebanyak 23 senyawa karbonil yang volatil, diantaranya adalah heptanal dan beberapa keton aromatik yang menyebabkan off-flavor.

Warna $S$. platensis media budidaya air laut dan air tawar hampir tidak berbeda secara visual yaitu berwarna 
Tabel 1. Karakteristik aroma/bau dan warna biomassa kering bubuk S. platensis

\begin{tabular}{lll}
\hline Karakteristik & Media air laut & Media air tawar \\
\hline Aroma/bau & Bau khas Spirulina seperti rumput laut & $\begin{array}{l}\text { Bau khas Spirulina seperti rumput laut } \\
\text { segar, aroma amis sangat lemah }\end{array}$ \\
& Legar, aroma amis lemah & L: 33,52, a: $-4,70$ b: $+0,20$
\end{tabular}

hijau tua. Warna biomassa $S$. platensis terutama dipengaruhi oleh kandungan klorofil serta fikosianin. Hasil pengujian menunjukkan nilai kecerahan (L) yang hampir serupa, kedua sampel memiliki nilai a (-) yang menunjukkan cenderung berwarna hijau serta memiliki nilai b $(+)$ yang menunjukkan warna kuning. S. platensis budidaya air tawar menunjukkan warna hijau yang lebih dominan (a: -4,70) dibandingkan hasil budidaya air laut (a: -1,17). Namun demikian, pada nilai $b$ terlihat fenomena sebaliknya. Warna hijau terutama berasal dari khlorofil sedangkan warna kuning berasal dari betakaroten. Klorofil dan fikosianin dapat bervariasi dan dipengaruhi oleh media tumbuhnya, Setyaningsih dkk. (2011) menjelaskan bahwa $S$. fusiformis mengalami perbedaan pigmen pada umur panen yang berbeda. Perbedaan umur panen menyebabkan kandungan bahan organik dalam media berbeda.

Richmond (1988) menjelaskan bahwa apabila kondisi nitrogen dalam media melimpah, maka nitrogen akan digunakan untuk pertumbuhan dan disimpan dalam fikosianin. Demikian juga dengan sintesis klorofil yang dipengaruhi oleh kandungan fosfor dan nitrogen, sehingga proporsi klorofil dan fikosianin dapat mempengaruhi warna biomassa. Leema dkk. (2010) menyebutkan bahwa S. platensis yang dibudidayakan dengan media air laut memiliki rasio fikosianin/klorofil-a serta rasio betakaroten/klorofil-a yang lebih tinggi dibandingkan budidaya dengan media air tawar. Pengeringan dengan dehumidifier pada suhu rendah juga dapat mencegah degradasi klorofil sehingga warna biomassa tidak berubah. Koca dkk. (2007) menjelaskan bahwa pada pemanasan suhu tinggi dapat menyebabkan degradasi klorofil menjadi kecoklatan.

Distribusi ukuran partikel serta densitas pada sampel $S$. platensis (Tabel 2) menunjukkan perbedaan. Densitas sampel media air tawar lebih kecil dibandingkan dari air laut. Sebaran partikel dapat mempengaruhi densitas dari biomassa tersebut, terlihat bahwa ukuran partikel yang semakin kecil dengan persentase yang lebih besar akan menyebabkan densitas menjadi lebih kecil, demikian pula sebaliknya. Densitas ini terutama dapat berhubungan dengan kelarutannya dan sifat fungsional lainnya. S. platensis yang dibudidayakan di India Selatan dilaporkan memiliki densitas 0,62-0,85 g/mL (Anonim, 2011).

\section{Komposisi Proksimat Biomassa Kering S. platensis}

Sampel hasil budidaya air laut mempunyai kadar air $(6,18 \%)$, sedangkan budidaya air tawar sebesar 6,26\% $(p>$ $0,05)$. Sampel memenuhi persyaratan standar mutu bubuk kering Spirulina yaitu kadar air produk maksimal sebesar $7 \%$ wb atau 7,5\% db (Henrikson, 2009). Komposisi kimia (protein, lemak, abu dan karbohidrat) dari berbagai sampel dapat dilihat pada Tabel 3. Markou dkk. (2012) menjelaskan bahwa komposisi kimia $S$. platensis dapat dipengaruhi oleh media budidaya serta kondisi pertumbuhan biomassa saat panen (Setyaningsih dkk., 2011). Hasil penelitian ini

Tabel 2. Sebaran ukuran partikel dan densitas S. platensis yang dibudidayakan dengan air laut dan air tawar

\begin{tabular}{|c|c|c|c|c|c|c|c|c|c|c|}
\hline \multirow{2}{*}{ Media } & \multicolumn{9}{|c|}{ Ukuran partikel (\%) } & \multirow{2}{*}{$\begin{array}{l}\text { Densitas } \\
(\mathrm{g} / \mathrm{mL})\end{array}$} \\
\hline & $>710 \mu \mathrm{m}$ & $600-710 \mu \mathrm{m}$ & $355-600 \mu \mathrm{m}$ & $250-355 \mu \mathrm{m}$ & $150-250 \mu \mathrm{m}$ & $106-150 \mu \mathrm{m}$ & $63-106 \mu \mathrm{m}$ & $38-63 \mu \mathrm{m}$ & $<38 \mu \mathrm{m}$ & \\
\hline Air laut & 0 & 0,02 & 11,35 & 18,21 & 18,41 & 12,37 & 16,19 & 14,58 & 8,89 & $0,69^{b}$ \\
\hline Air tawar & 0 & 0 & 0,02 & 0,15 & 4,58 & 7,64 & 18,94 & 45,51 & 23,16 & $0,51^{\mathrm{a}}$ \\
\hline
\end{tabular}

Nilai dengan huruf superskrip yang berbeda dalam kolom densitas menunjukkan perbedaan yang nyata $(p<0,05)$. 
menunjukkan bahwa kadar protein, lemak dan karbohidrat tidak berbeda $(p>0,05)$. Sampel yang diuji memiliki kadar protein diatas $60 \%$, Henrikson (2009) dan Tietze (2004) mengungkapkan bahwa kandungan protein $S$. platensis dapat mencapai hingga $60-70 \%$ berat keringnya. Belay (2008) menyebutkan bahwa Spirulina komersial memiliki kadar protein sebesar $63 \%$, sedangkan Certified Organic Spirulina dari India Selatan melaporkan kadar protein dalam produksi mereka dapat bervariasi setiap batch dengan rentang 56-69\% (Anonim, 2011).

Tabel 3. Komposisi kimia (db) S. platensis dari budidaya air laut dan air tawar

\begin{tabular}{lllll}
\hline Media & Protein $\%$ & Lemak $\%$ & Abu \% & KH by diff. $\%$ \\
\hline Air laut & $63,45^{\mathrm{a}}$ & $0,59^{\mathrm{a}}$ & $7,55^{\mathrm{a}}$ & $28,41^{\mathrm{a}}$ \\
Air tawar & $62,83^{\mathrm{a}}$ & $0,51^{\mathrm{a}}$ & $5,93^{\mathrm{b}}$ & $30,73^{\mathrm{a}}$ \\
\hline
\end{tabular}

Nilai dengan huruf superskrip yang berbeda dalam kolom yang sama menunjukkan perbedaan yang nyata $(p<0,05)$.

Kadar lemak sampel sangat rendah dibawah $1 \%$. Meskipun tidak berbeda secara statistik namun sampel dengan media air laut cenderung memiliki kadar lemak yang lebih tinggi. Borowitzka dan Borowitzka (1988) menyebutkan bahwa salinitas yang lebih tinggi dapat meningkatkan kadar lemak mikro alga. Henrikson (2009) menyebutkan bahwa rata-rata kandungan lemak Spirulina berkisar antara 4-7\%. Bahkan apabila variasi sumber nitrogen dan sumber karbon bervariasi, lemak dapat mencapai 11-25\% (Madkour dkk., 2012). Dugaan sementara pada kandungan lemak yang rendah dari komposisi pupuk yang digunakan oleh produsen. Kandungan lemak yang rendah menguntungkan karena memiliki daya simpan yang lama. Masa kadaluarsa yang disebutkan adalah selama 2 tahun. Belay (2008) bahkan menyebutkan bahwa biomassa kering Spirulina dengan pengeringan spray drying dikemas dengan aluminium foil dapat bertahan hingga 4 tahun. Percobaan dengan percepatan menunjukkan hasil bahwa kandungan antioksidan Spirulina masih dalam kondisi sangat baik pada penyimpanan suhu 40 ${ }^{\circ} \mathrm{C}$, RH 75\% selama 9 bulan (Anonim, 2011).

Kandungan karbohidrat pada sampel cukup tinggi yaitu diatas $25 \% \mathrm{db}$. Beberapa peneliti menyebutkan bahwa kandungan karbohidrat berkisar antara $15-25 \%$ wb (Belay, 2008) dan 13\% wb (Sekharam dkk., 1987). Tingginya kadar karbohidrat dibandingkan hasil penelitian lainnya disebabkan kandungan lemak pada sampel yang rendah sehingga dengan perhitungan kandungan karbohidrat dengan metode pengurangan (by difference) akan meningkatkan proporsi karbohidrat (Choi dkk., 2008) menjelaskan bahwa media budidaya yang mengandung amonium menghasilkan biomassa kering yang tinggi, namun demikian kandungan total asam amino yang tinggi diperoleh dari media yang mengandung urea, sedangkan jika nitrat sebagai sumber nitrogen maka akan dijumpai klorofil dalam jumlah yang tinggi. Markou dkk. (2012) menambahkan bahwa kandungan fosfor yang terbatas dalam media dapat menyebabkan peningkatan kandungan karbohidrat dan menyebabkan penurunan protein. Sassano dkk. (2010) menjelaskan, apabila sumber nitrogen yang digunakan berupa amonium hidroklorida dalam sistem budidaya yang kontinyu terlihat hubungan antara kadar protein dengan kadar karbohidrat, apabila kadar amonium meningkat maka akan meningkatkan kandungan protein dan menurunkan kandungan karbohidrat. Apabila kadar protein berkisar antara 50\% maka kandungan karbohidrat berkisar antara 23\%. Dalam kondisi amonium yang rendah maka biomassa dapat mengandung protein hanya sebesar $20 \%$ sedangkan kandungan karbohidrat dapat mencapai $65 \%$.

Kadar abu S. platensis dipengaruhi oleh media budidayanya $(p<0,05)$. Sampel budidaya air laut memiliki kadar abu yang lebih tinggi dibandingkan air tawar. Hu (2004) mengemukakan bahwa faktor lingkungan seperti cahaya, suhu, nutrien dan salinitas tidak hanya mempengaruhi fotosintesis dan produktivitas biomassa sel tetapi dapat mempengaruhi bentuk, aliran aktivitas metabolisme seluler yang berdampak pada dinamika komposisi sel. Kandungan abu yang lebih besar pada sampel budidaya air laut disebabkan karena air laut secara alamiah mengandung mineral yang lebih tinggi dibandingkan air tawar, sehingga mempengaruhi media tempat tumbuhnya S. platensis. Nutrien dalam media seperti garam, karbonat dapat terbawa ke dalam biomassa sehingga kadar abu pada sampel asal budidaya laut memiliki kadar abu yang lebih tinggi. Selain itu, pada saat panen, apabila biomassa alga tidak dibilas dengan cukup air asam untuk membersihkan senyawa karbonat maka dapat mengandung kadar abu hingga mencapai $25 \%$ dan kandungan protein dapat menurun menjadi 50\% atau kurang (Richmond, 1988).

\section{Kandungan Kalsium, Magnesium dan Fosfor S. platensis}

Media budidaya mempengaruhi kandungan kalsium $(\mathrm{Ca})$, magnesium $(\mathrm{Mg})$ dan fosfor $(\mathrm{P})$ sampel $(p<0,05)$. Sampel dari budidaya air laut memiliki kadar mineral yang lebih tinggi (Tabel 4.). Hal ini sesuai dengan pernyataan beberapa peneliti bahwa kandungan mineral spirulina dipengaruhi oleh kondisi budidayanya (Planes dkk., 2002; Markou dkk., 2012). Lebih tingginya kadar Ca, Mg dan P pada S. platensis media budidaya air laut sejalan dengan kandungan abunya yang juga lebih tinggi dibandingkan media air tawar. Budidaya dengan tingkat salinitas yang tinggi menyebabkan garam mineral terakumulasi dalam biomassa $S$. platensis. Kadar kalsium S. platensis media air laut hampir lima kali lipatnya dibandingkan dari air tawar. Dengan demikian Spirulina budidaya air laut dapat berpotensi sebagai alternatif sumber kalsium. 
Tabel 4. Kadar kalsium (Ca), magnesium (Mg), fosfor (P) dan rasio $\mathrm{Ca} / \mathrm{P}$ S. platensis dari budidaya air laut dan air tawar

\begin{tabular}{lcccc}
\hline Media & $\begin{array}{c}\text { Kalsium } \\
\mathrm{mg} \mathrm{Ca} / 100 \mathrm{~g} \\
(\mathrm{db})\end{array}$ & $\begin{array}{c}\text { Magnesium } \\
\mathrm{mg} \mathrm{Mg} / 100 \mathrm{~g} \\
(\mathrm{db})\end{array}$ & $\begin{array}{c}\text { Fosfor } \\
\mathrm{Mg} \mathrm{P} / 100 \mathrm{~g} \\
(\mathrm{db})\end{array}$ & Rasio Ca:P \\
\hline Air laut & $512,53^{\mathrm{a}}$ & $345,62^{\mathrm{a}}$ & $919,32^{\mathrm{a}}$ & $1: 1,79^{\mathrm{a}}$ \\
Air tawar & $110,89^{\mathrm{b}}$ & $180,66^{\mathrm{b}}$ & $536,12^{\mathrm{b}}$ & $1: 4,96^{\mathrm{b}}$ \\
\hline
\end{tabular}

Nilai dengan huruf superskrip yang berbeda dalam kolom yang sama menunjukkan perbedaan yang nyata $(p<0,05)$.

Dalam proses absorbsi, kalsium dan fosfor saling berpengaruh sangat erat. Untuk absorbsi kalsium yang baik, diperlukan perbandingan $\mathrm{Ca}: \mathrm{P}$ di dalam rongga usus (dalam makanan) 1:1 sampai 1:3. Perbandingan Ca:P yang lebih besar dari 1:3 akan menghambat penyerapan kalsium, sehingga makanan yang demikian akan menimbulkan penyakit defisiensi kalsium (Sediaoetama, 2000). Rasio Ca:P sampel asal budidaya laut berkisar 1,79 , lebih baik dibandingkan sampel asal budidaya air tawar. Perbandingan tersebut hampir serupa dengan yang diungkapkan oleh Belay (2008) dan Salmean dkk. (2015), bahwa Spirulina yang beredar komersial di USA memiliki kandungan P kurang lebih hampir 2 kali lipatnya dibandingkan Ca. Rasio Ca:P pada Spirulina asal budidaya air tawar terlihat lebih tinggi, meskipun kandungan fosfornya lebih rendah dibandingkan dari laut. Hal ini disebabkan kandungan kalsiumnya yang lebih rendah. Apabila dihubungkan dengan rasio yang seimbang agar dapat diabsorpsi dengan baik, maka sampel dari air tawar tidak memenuhi kriteria tersebut. Menurut Brody (1994), konsumsi fosfor yang tinggi akan menyebabkan meningkatnya ekskresi kalsium dalam feses dan menurunkan ekskresi kalsium dalam urin, namun tidak mempengaruhi keseimbangan kalsium tubuh. Ca dan Mg diserap di intestinum, sehingga keberadaan magnesium juga dapat mempengaruhi absorpsi kalsium karena memiliki valensi ion yang sama.

Pada S. platensis air tawar kandungan magnesium terlihat lebih besar dibandingkan kalsiumnya. Melihat fenomena ini maka diduga S. platensis dari air laut jika digunakan sebagai sumber kalsium akan lebih baik dibandingkan yang berasal dari air tawar. Salmean dkk. (2015) menjelaskan bahwa sianobakteria seperti Spirulina merupakan bahan pangan bebas oksalat, sehingga availabilitas kalsiumnya tinggi dan mudah diabsorbsi. Absorbsi kalsium selain dipengaruhi oleh ion dengan valensi yang sama, juga dipengaruhi oleh solubilitas, asiditas, lemak dan serat dalam diet serta ion $\mathrm{Ca}$ dalam kondisi terion atau terikat. Lee dkk. (2000) mengungkapkan bahwa ion $\mathrm{Ca}$ ditemukan berada terikat secara ionik dengan sulfated polisakarida.

\author{
Kandungan Gula Total, Pati dan Serat Pangan $S$. \\ platensis
}

Kandungan gula total, pati serta serat pangan $S$. platensis dipengaruhi oleh media budidaya $(p<0,05)$ (Tabel 5). Terdapatnya pati pada $S$. platensis dapat disebabkan karena sampel dipanen pada akhir fasa stasioner. Pada akhir fasa stationer fotosintesis terus berlanjut namun terjadi penurunan laju ketika nitrogen dalam sel turun hingga di bawah nilai batas ambang. Kondisi kekurangan nitrogen dapat mengakibatkan terjadinya akumulasi pati. Hu (2004) menyebutkan bahwa pada mikroalga genus Chlorella, dalam kondisi demikian sebagian strain mengalami akumulasi pati dan beberapa strain mengalami akumulasi lipid. Jika masa panen dilakukan pada waktu yang sama, maka perbedaan kadar pati antara sampel budidaya air laut dan air tawar dijelaskan oleh Brown dan Borowitzka (1979) karena pati mengalami pemecahan akibat biosintesis gliserol, meskipun mekanisme molekular distribusi atom $\mathrm{C}$ antara pati dan gliserol pada mikroalga belum diketahui.

Kandungan gula total $S$. platensis dengan media budidaya air laut lebih rendah dibandingkan dengan media air tawar, yaitu $0,09 \%$ db dengan kandungan pati yang lebih tinggi yaitu 6,9\% db. Shekharam dkk. (1987) mengungkapkan komponen karbohidrat dalam S. platensis berupa glukosa, rhamnosa, manosa, xylosa dan galaktosa. Pada fraksi polisakarida larut asam ditemukan sebanyak 97\% glukosa dan 0,4\% sulfat (Shekharam dkk., 1989), sedangkan pada fraksi polisakarida yang larut dalam air terutama mengandung rhamnosa (Shekharam dkk., 1987, Chaiklahan dkk., 2013). Shekharam dkk. (1989) menjelaskan bahwa fraksi polisakarida larut asam tersebut merupakan glukan yang termasuk ke dalam serat pangan. Apabila polisakarida larut asam dihidrolisis secara partial menggunakan asam diperoleh glukosa, maltosa, isomaltosa, dan maltotriosa. Hidrolisis glukan secara enzimatis dengan $\alpha$-amilase, $\alpha$ glukosidase dan pullulanase menghasilkan glukosa dan maltosa. Glukan memiliki rantai utama $\alpha-1,4$ dan bercabang pada $\alpha-1,6$, mungkin menjadi polisakarida cadangan

Tabel 5. Kadar gula total, pati, serat tak larut (STLA), serat larut (SLA) dan total serat larut (TSP) S. platensis dari media budidaya air laut dan air tawar (\% berat kering)

\begin{tabular}{lccccc}
\hline Media & Gula total & Pati & STLA & SLA & TSP \\
\hline Air laut & $0,09^{\mathrm{a}}$ & $6,9^{\mathrm{a}}$ & $24,18^{\mathrm{a}}$ & $0,63^{\mathrm{a}}$ & $24,81^{\mathrm{a}}$ \\
Air tawar & $0,72^{\mathrm{b}}$ & $2,11^{\mathrm{b}}$ & $25,18^{\mathrm{a}}$ & $1,25^{\mathrm{b}}$ & $26,43^{\mathrm{b}}$ \\
\hline
\end{tabular}

Nilai dengan huruf superskrip yang berbeda dalam kolom yang sama menunjukkan perbedaan yang nyata $(p<0,05)$. 
spirulina. Belay (2008) menyebutkan bahwa 43\% komponen karbohidrat dalam S. platensis merupakan serat pangan. Hasil uji menunjukkan proporsi serat pangan yang terbanyak dari S. platensis adalah serat pangan tak larut. Babadzhanov dkk. (2004) menyebutkan bahwa S. platensis mengandung hemiselulosa dan pektin. Informasi tentang variasi serat pangan larut dan tak larut pada Spirulina masih sangat terbatas. Beberapa peneliti menyebutkan bahwa penambahan S. platensis $7 \%$ dalam biskuit dapat meningkatkan serta pangan sebesar 2,3\% (Singh dkk., 2015), penambahan sebesar 0,4\% dalam minuman jelly meningkatkan kandungan serat pangan sebesar 5\% (Trilaksani dkk., 2015). Variasi kandungan serat pangan dalam S. platensis juga dilaporkan oleh Trilaksani dkk. (2015) S. platensis hasil kultur memiliki total serat pangan sebanyak $11,24 \% \mathrm{db}$, sedangkan pada Spirulina komersial tidak terdeteksi adanya serat pangan. Sampel dari budidaya air tawar terlihat memiliki total serat pangan yang lebih tinggi dibandingkan sampel dari budidaya air laut. Hal ini dimungkinkan tingginya mineral dalam budidaya air laut, sehingga berikatan dengan serat pangan dalam S. platensis, dengan demikian serat pangan dalam kondisi bebasnya lebih sedikit dan berimplikasi pada hasil pengukuran serat pangan yang lebih rendah.

\section{Karakteristik Sifat Fungsional Biomassa Kering Bubuk Spirulina platensis}

Sifat fungsional Water Holding Capacity (WHC) dan Oil Holding Capacity (OHC) S. platensis dipengaruhi oleh asal budidaya $(p<0,05)$, sedangkan WSI (Solubility), kemampuannya membentuk busa (Foaming Capacity, FC) serta kapasitas emulsinya (Emulsion Capacity, EC) tidak dipengaruhi oleh asal budidaya $(p>0,05)$ (Tabel 6). Angka WHC yang diperoleh pada penelitian ini mirip dengan WHC pada isolat protein kacang-kacangan yaitu berkisar antar 3-4 mL/g (Subagio, 2006; Onyango dkk., 2004). WHC penting dalam sifat-sifat fungsional pangan yang dipengaruhi oleh ukuran pori-pori, muatan molekul protein.

Tabel 6. Sifat fungsional S. platensis dari budidaya air laut dan air tawar

\begin{tabular}{lccccc}
\hline Asal & $\begin{array}{c}\text { WHC } \\
\mathrm{mL} / \mathrm{g}\end{array}$ & $\begin{array}{c}\text { WSI } \\
\%\end{array}$ & $\begin{array}{c}\text { OHC } \\
\mathrm{mL} / \mathrm{g}\end{array}$ & $\begin{array}{c}\mathrm{EC} \\
\mathrm{mL} / \mathrm{g}\end{array}$ & FC \\
\hline Laut & $4,46^{\mathrm{a}}$ & $51,30^{\mathrm{a}}$ & $2,35^{\mathrm{a}}$ & $104,57^{\mathrm{a}}$ & $1,49^{\mathrm{a}}$ \\
Tawar & $3,37^{\mathrm{b}}$ & $50,85^{\mathrm{a}}$ & $2,85^{\mathrm{b}}$ & $100,84^{\mathrm{a}}$ & $1,58^{\mathrm{a}}$ \\
\hline
\end{tabular}

Nilai dengan huruf superskrip yang berbeda dalam kolom yang sama menunjukkan perbedaan yang nyata $(p<0,05)$

Keterangan: WHC: Water Holding Capacity, WSI: Water Solule Index, OHC: Oil Holding Capacity, FC: Foaming Capacity, EC: Emulsifying Capacity
Adebowale dan Lawal, (2004) berpendapat bahwa nilai WHC dipertimbangkan sebagai penyiapan produk pangan yang berkaitan dengan viskositas pangan seperti sup, adonan dan produk bakery.

Nilai OHC sampel yang diuji mirip dengan $\mathrm{OHC}$ isolat protein biji enceng gondok sebesar 2,54\% (Subagio, 2006). Kemampuan mengikat lemak yang cukup besar ini dimungkinkan karena asam amino yang terdapat dalam $S$. platensis terutama asam amino yang bersifat hidrofobik. Richmond (1988) mengungkapkan bahwa Spirulina yang diproduksi di Mexico mengandung 17 asam amino. Setyaningsih dkk. (2011) juga menemukan asam amino yang sama pada S. fusiformis. Cohen (1997) menjelaskan bahwa Spirulina terutama mengandung asam amino leusin (10,9\% dari total asam amino), valin $(7,5 \%)$ dan iso leusin $(6,8 \%)$. Ketiga jenis asam amino tersebut merupakan asam amino yang bersifat hidrofobik. Sampel yang berasal dari air tawar memiliki WHC yang lebih rendah dan memiliki $\mathrm{OHC}$ yang lebih tinggi dibandingkan sampel air laut. Jika dihubungkan dengan densitasnya keadaan ini bertentangan, karena pada sampel air tawar justru densitasnya lebih rendah. Hal yang mungkin dapat menerangkan bahwa media budidaya mungkin mempengaruhi konformasi protein $S$. platensis, sehingga proporsi asam amino hidrofilik dan hidrofobik berada dalam posisi yang berbeda, akibatnya terjadi perbedaan kapasitas pengikatan air dan lemak.

Kemampuan S. platensis untuk larut air (WSI) terlihat kurang baik, meskipun kadar proteinnya tinggi. Hal ini dijelaskan oleh Chaiklahan dkk. (2013) bahwa $S$. platensis akan lebih mudah larut dalam air bersuhu tinggi, ataupun pada larutan yang asam. Pengujian yang dilakukan menggunakan air suhu ruangan, dengan demikian dapat dipahami kelarutannya yang cukup rendah tersebut.

Pengujian kemampuan membentuk busa (FC) dilakukan pada sampel tanpa pengaturan $\mathrm{pH}$, sampel berada pada $\mathrm{pH}$ alamiahnya (pH 6,3). Sampel asal budidaya laut dan tawar memiliki kemampuan yang sama dalam membentuk busa. Devi dan Venkataraman (1984) menyebutkan bahwa kemampuan membentuk busa $S$. platensis akan menurun pada titik isoelektriknya yaitu pada $\mathrm{pH} 3$, dan akan maksimal pada $\mathrm{pH}$ alkali $(\mathrm{pH} 10)$. Hal ini dimungkinkan karena $S$. platensis dibudidayakan pada $\mathrm{pH}$ yang alkali $(\mathrm{pH}$ 8-11). Kemampuan membentuk busa ini dapat dimanfaatkan pada saat ditambahkan pada produk makanan terutama pada minuman.

Kapasitas $S$. platensis dalam proses emulsifikasi kedua sampel cukup besar. Namun demikian, stabilitas emulsinya rendah, setelah 24 jam emulsi akan terpisah. Devi dan Ventakaram (1984) menyebutkan bahwa defatted S. platensis memiliki kapasitas emulsi yang lebih rendah dibandingkan defatted kedelai. Sampel meskipun tidak mengalami defatted, 
namun kadar lemaknya sangat rendah hanya sebesar 0,51 dan 0,59\% saja, hal ini dapat mempengaruhi stabilitas emulsinya. Sifat emulsifikasi ini diperlukan dalam proses pembuatan produk pangan serta pada proses pencernaan S. platensis dalam tubuh.

\section{KESIMPULAN}

Budidaya $S$. platensis dalam media air laut meningkatkan kandungan abu dan mineral $(\mathrm{Ca}, \mathrm{Mg}, \mathrm{P})$. S. platensis dari media budidaya air laut berpotensi sebagai alternatif sumber kalsium. Media budidaya air laut juga meningkatkan kandungan karbohidrat (pati dan total serat pangan) biomassa namun menurunkan kandungan gula total serta serat pangan. Serat pangan $S$. platensis terutama berupa serat pangan tak larut. Sifat fungsional WHC S. platensis hasil budidaya air laut lebih tinggi dibandingkan air tawar, namun sifat fungsional OHC sebaliknya. Media budidaya tidak mempengaruhi WSI, kapasitas membentuk busa dan emulsifikasi.

\section{DAFTAR PUSTAKA}

Adebowale, K.O. dan Lawal, O.S. (2004). Comparative study of the functional properties of bambarra groundnut (Voandzeia subterranean), jack bean (Canavalia ensiformis) and mucuna bean (Mucuna pruriens) flours. Food Research International 37(4): 355-365.

Aguero, J., Lora, J., Estrada, K., Concepcion, F., Nunez, A., Rodriguez, A. dan Pino, J.A. (2003). Volatile components of a commercial sample of the blue-green algae Spirulina platensis. Journal o Essential Oil Research 15(2): 114-117.

Anonim. (2011). Notice to US Food and Drug Administration that the use of Certified Organic Spirulina (Arthrospira platensis) is Generally Recognize as Safe. E.I.D. Parry (India) Limited, Parry Nutraceuticals Division, Dare House. Chennai, India.

AOAC. (1995). Official Method of Analysis. Association of Official Analytical Chemist(AOAC). 16 $6^{\text {th }}$ Edition. Published by the Association of Official Analytical Chemist. Washington DC, USA.

Asp, N. G., Johansson, C. G., Hallmer, H. dan Siljestroem, M. (1983). Rapid enzymic assay of insoluble and soluble dietary fiber. Journal of Agricultural and Food Chemistry 31(3): 476-482.

Babadzhanov, A.S., Abdusamatova, N., Yusupova, F.M., Faizullaeva, N., Mezhlumyan, L.G. dan Malikova, M.K. (2004). Chemical composition of Spirulina platensis cultivated in Uzbekistan. Chemistry of Natural Compounds 40(3): 276-279.

Belay, A. (2008). Spirulina (Arthrospira): Production and Quality Assurance. Dalam: Gershwin M.E. dan A. Belay (ed.). hal 1-26. Spirulina in Human. CRC Press.

Borowitzka, M.A. dan Borowitzka, L.J. (1988). Micro-algal Biotechnology. Cambridge University Press.

Brody (1994). Human Nutrition in The Developing World. FAO Food and Nutrition Series No. 29. Food and Agricultural Organization of The United Nation. Rome.

Brown, A.D. dan Borowitzka, L.J. (1979). Halotolerance of Dunaliella. Dalam: Levandowsky, M., dan Huntner, S.H. (Eds.), hal 139-190. Biochemistry and Physiology of Protozoa. Academic Press, New York.

Chaiklahan, R., Chirasuwan, N., Triratana, P., Loha, V., Tia, S. dan Bunnag, B. (2013). Polysaccharide extraction from Spirulina sp. and its antioxidant capacity. International Journal of Biological Macromolecules 58: 73-78.

Choi, G.G., Bae, M.S., Ahn, C.Y. dan Oh, H.M. (2008). Induction of axenic culture of Arthrospira (Spirulina) platensis based on antibiotic sensitivity of contaminating bacteria. Biotechnology Letters 30(1): 87-92.

Ciferri, O. (1983). Spirulina, the edible microorganism. Microbiological Reviews 47: 551-578.

Cohen, Z. (1997). The chemicals of Spirulina. Dalam: Vonshak, A. (ed). Spirulina platensis (Arthrospira): Physiology, Cell-biology and Biotechnology, hal 175204. Taylor and Francis, London.

Costa, J.A.V., Colla, L.M., Filho, P.D., Kabke, K. dan Weber, A. (2002). Modelling of Spirulina platensis growth in fresh water using response surface methodology. World Journal Microbiology Biotechnology 18: 603-607.

Devi, M.A. dan Venkataraman, L.V. (1984). functional properties of protein products of mass cultivated bluegreen alga Spirulina platensia. Journal of Food Science 49(1): 24-27.

Dubois, M., Gilles, K.A., Hamilton, J. K., Rebers, P. dan Smith, F. (1956). Colorimetric method for determination of sugars and related substances. Analytical chemistry 28(3): 350-356.

Gupta, S., Hrishikeshvan, H.J. dan Sehajpal, P.K. (2010). Spirulina protects againts Rosiglitazone induced osteoporosis in insulin resistance rats. Diabetes Research and Clinical Practice 87: 38-43.

Habib, M.A.B., Parvin, M., Huntington, T.C. dan Hasan, M.R. (2008). A review on culture, production and use 
of spirulina as food for humans and feeds for domestic animals and fish. Food and Agriculture Organization of The United Nations.

Henrikson, R. (2009). Earth Food Spirulina. Essential Fatty Acid and Phytonutrients. Ronore Enterprises, Inc. California.

$\mathrm{Hu}$, Q. (2004). Environmental effects on cell composition. Dalam: Richmond, A (Ed). Handbook of Microalgal Culture: Biotechnology and Applied Science, hal 8393. Oxford: Blackwell Science Publishing.

Jiminez, C., Cossio, B.R. dan Niell, F.X. (2003). Relationship Between Physiochemical variables and productivity in open ponds for the production of Spirulina: A predictive model of algal yield. Aquaculture 221(1-4): 331-345.

Koca, N., Karadeniz, F. dan Burdurlu, H.S. (2007). Effect of $\mathrm{pH}$ on chlorophyll degradation and colour loss in blanched green peas. Food Chemistry 100(2): 609-615.

Lee, J., Hayashi, T., Hayashi, K. dan Sankawa, U. (2000). Structural analisis of calcium spirulan (Ca-SP)-derived oligosaccharides using electrospray ionization mass spectrometry. Journal Natural Product 63: 136-138.

Leema, J.M., Kirubagaran, R., Vinithkumar, N.V., Dheenan, P.S. dan Karthikayulu, S. (2010). High value pigment production from Arthrospira (Spirulina) platensis cultured in seawater. Bioresource Technology 101(23): 9221-9227.

Lodi, A., Binaghi, L., De Faveri, D., Carvalho, J.K.L., Convert, A. dan Del-Borghi, M. (2005). Fed batch mixotrophic cultivation of Arthospira (Spirulina) platensis (Cyanophyceae) with carbon source feeding. Annals of Microbiology 55(3): 181-185.

Madkour, F.F., Kamil, A.E.W. dan Nasr, H.S. (2012). Production and nutritive value of Spirulina platensis in reduced cost media. The Egyptian Journal of Aquatic Research 38(1): 51-57.

Makri, E., Papalamprou, E. dan Doxastakis, G. (2005). Study of functional properties of seed storage proteins from indigenous European legume crops (lupin, pea, broad bean) in admixture with polysaccharides. Food Hydrocolloids 19(3): 583-594.

Marek, R.W., Bazin, M.J. dan Hohn, P. (1987) Computer control of carbon-nitrogen ratio in Spirulina platensis. Biotechnology and Bioengineering 29: 520-528.

Markou, G., Chatzipavlidis I. dan Georgakakis, D. (2012). Effects of phosphorus concentration on the biomass composition of Arthrospira (Spirulina) platensis. World Journal Microbiology Biotechnology 28: 2661-2670.
Marquez, F.J., Nishio, N. dan Nagai, S. (1995). Enhancement of biomassa and pigment production during growth of Spirulina platensis in mixotrophic culture. Journal Chemical Technology Biotechnology 962: 159-164.

Marquez, F.J., Sasaski, K., Kakizono, T, Nishio, N. dan Nagai, S. (1993). Growth characteristic of Spirulina platensis in mixotropic and heterotrophic condition. Journal Fermentation Bioengineering 76(5): 408-410.

Onyango, C., Henle, T., Ziems, A., Hofmann, T. dan Bley, T. (2004). Effect of extrusion variables on fermented maize-finger millet blend in the production of uji. $L W T$ Food Science and Technology 37(4): 409-415.

Planes, P., Rouanet, J.M., Laurent, C., Baccou, J.C., Besançon, P. dan Caporiccio, B. (2002). Magnesium bioavailability from magnesium-fortified spirulina in cultured human intestinal Caco- 2 cells. Food Chemistry 77(2): 213-218.

Ravelonandro, P.H., Ratianarivo, D.H., Cassan, C.J., Isambert, A. Dan Raherimandimby, M. (2011). Improvement of the growth of Arthrospira (Spirulina) platensis from Toliara (Madagascar): effect of agitation, salinity and $\mathrm{CO} 2$ addition. Food and Bioproducts Processing 89: 209-216.

Richmond, A. (1988). Spirulina. Dalam: Borowitzka, M.A. dan L.J. Borowitzka. 1988. (ed.). Microalgae Biotechnology, hal 85-121. Cambridge University Press, England.

Salmean, G.G., Castillo, L.F., Cavallos, G.C. (2015) Nutritional and toxicological aspects of Spirulina (Arthrospira). Nutricion Hospitalaria 32(1): 34-40.

Sassano, C.E.N., Gioielli, L.A., Ferreira, L.S., Rodrigues, M.S., Sato, S., Converti, A. dan Carvalho, J.C.M. (2010). Evaluation of the composition of continuouslycultivated Arthrospira (Spirulina) platensis using ammonium chloride as nitrogen source. Biomass and Bioenergy 34(12): 1732-1738.

Sediaoetama, A.D. (2000). Ilmu Gizi (untuk Mahasiswa dan Profesi di Indonesia). Jilid 2. Dian Rakyat, Jakarta.

Setyaningsih, I., Saputra, A.T. dan Uju. (2011). Komposisi kimia dan kandungan pigmen Spirulina fusiformis pada umur panen yang berbeda dalam media pupuk. Jurnal Pengolahan Hasil Perikanan Indonesia 14(1): 63-69.

Shekharam, K.M., Venkataraman, L.V. dan Salimath, P.V. (1987). Carbohydrate composition and characterization of two unusual sugars from the blue green alga Spirulina platensis. Phytochemistry 26(8): 2267-2269. 
Shekharam, M.K., Venkataraman, L.V. dan Salimath, P.V. (1989). Structural studies of a glucan isolated from blue green alga Spirulina platensis. Food Chemistry 31: 8591.

Singh, P., Singh, R., Jha, A., Rasane, P. dan Gautam, A.K. (2015). Optimization of a process for high fibre and high protein biscuit. Journal of Food Science and Technology 52(3): 1394-1403.

Subagio, A. (2006). Characterization of hyacinth bean (Lablab purpureus (L.) sweet) seeds from Indonesia and their protein isolate. Food chemistry 95(1): 65-70.

Suminto (2009). Penggunaan jenis media kultur teknis terhadap produksi dan kandungan nutrisi sel Spirulina platensis. Jurnal Saintek Perikanan 4(2): 53-61.

Tietze, H.W. (2004). Spirulina. Micro Food Macro Blessing. $4^{\text {th }}$ ed. Harald W. Tietze Publishing. Australia.
Trilaksani, W., Setyaningsih, I. dan Masluha, D. (2015). Formulation of red seaweed and Spirulina platensis based jelly drinks. Jurnal Pengolahan Hasil Perikanan Indonesia 18(1): 74-82.

Tri-Panji, Suharyanto, Rakaya, E. dan Hasim (1995). Penggunaan serum lateks skim sebagai medium produksi protein sel tunggal oleh Spirulina platensis. Menara Perkebunan 63(3): 114-122.

Urbano, G., Lopez-Jurado, M., Fernandez, M., Moreu, M.C., Porres-Foulquie, J., Frias, J. dan Vidal-Valverde, C. (1999). Ca and P bioavailability of processed lentils as affected by dietary fiber and phytic acid content. Nutrition Research 19(1): 49-64.

Winarno, F.G. (2008). Kimia Pangan dan Gizi. Edisi Revisi. PT. Gramedia Pustaka Utama, Jakarta.

Yu, J., Ahmedna, M. dan Goktepe, I. (2007). Peanut protein concentrate: Production and functional properties as affected by processing. Food Chemistry 103(1): 121129. 